\title{
Homenagem aos 50 anos de Ciência da Informação no Brasil: antecedentes históricos
}

A Ciência da Informação em Revista, periódico quadrimestral do Programa de PósGraduação em Ciência da Informação da Universidade Federal de Alagoas, dedica o volume 7 aos $\mathbf{5 0}$ anos de Ciência da Informação no Brasil. A ideia é prestar homenagens, via capa e Editorial da revista, a personalidades que marcaram os três tempos da área no país, os antecedentes históricos, a implantação e o desenvolvimento.

Este primeiro número, dedicado aos antecedentes históricos, reverencia, na pessoa da Bibliotecária Lydia de Queiroz Sambaquy, aos desbravadores, que contribuíram com o estabelecimento de uma infraestrutura de ciência, tecnologia e inovação, principalmente, na área de informação e documentação científica junto ao então Instituto Brasileiro de Bibliografia e Documentação (IBBD), atual Instituto Brasileiro de Informação em Ciência e Tecnologia (IBICT), que serviu de base para a implantação e o desenvolvimento da Ciência da Informação no Brasil.

Figura 1 - Capa do v. 7, n. 1, jan./abr. 2020, da Ciência da Informação em Revista

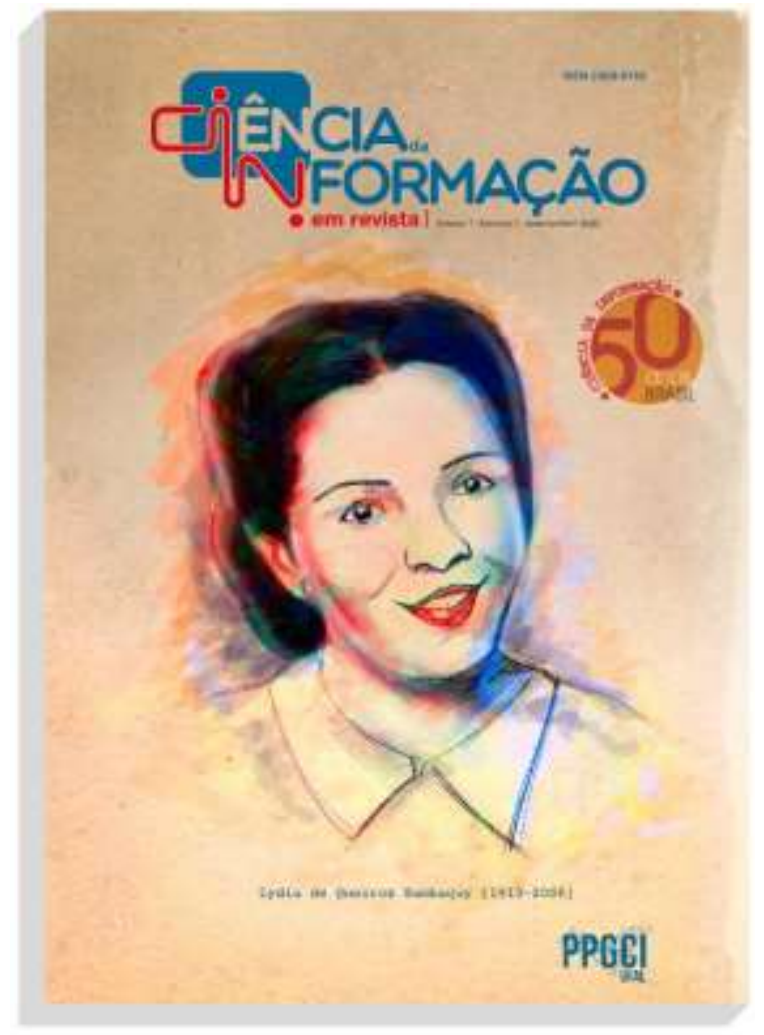

Tomando como referência este contexto institucional, a capa deste número (Figura 1) e o selo comemorativo (Figura 2) foram elaborados, por meio da metodologia TXM Branding, procurando, respectivamente, fazer referência a um dos marcos históricos da área, a partir da homenagem a uma personalidade que contribuiu com esses antecedentes, e registrar um símbolo comemorativo em alusão à passagem dos 50 anos de Ciência da Informação no Bra- 
sil. Com efeito, capa e selo estabelecem diálogos com a produção da homenageada e com o Editorial, em um processo de ressignificação, que, a um só tempo, recupera e atualiza parte da memória e da história.

Figura 2 - Conceito de capa e selo comemorativo

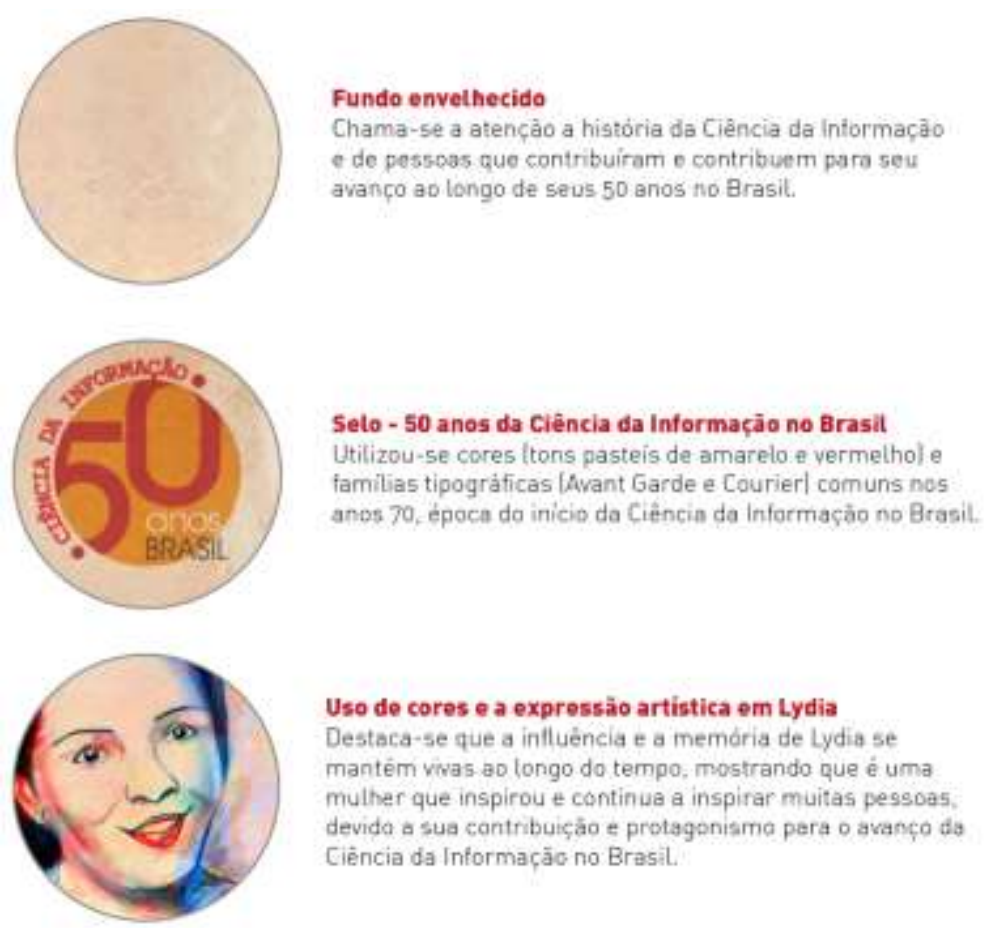

A Ciência da Informação em Revista agradece de modo muito especial à Professora Doutora Nanci Oddone, que aceitou o convite para contribuir com este número, na condição de Editora convidada. Agradece também a parceria com o periódico da Fundação Getúlio Vargas Fórum Educacional, que gentilmente concedeu os direitos de publicação e divulgação do artigo de autoria de Lydia de Queiroz Sambaquy "O IBBD e a informação científica", nele publicado no ano de 1988. Abrindo a seção de artigos, o texto discute a criação do IBBD e o significado dessa instituição para o desenvolvimento da informação e documentação em ciência e tecnologia no país.

\section{Edivanio Duarte de Souza \\ Ronaldo Ferreira de Araujo \\ Editores}

